\title{
Kansalaisrohkeus: Tottelemattomia yksilöitä, yhteisöjä, tutkijoita
}

Teppo Eskelinen, Tiina Seppälä ja Sanna Ryynänen

\section{TIIVISTELMÄ}

- Katsausteksti tarkastelee kansalaisrohkeutta ja kansalaistottelemattomuutta useista eri näkökulmista käsin, pohtien muun muassa yksilön ja kollektiivien organisoitumista epäoikeudenmukaisuuden ja epätasa-arvon vastustamiseksi, kansalaisuuteen liittyviä jännitteitä, erilaisia demokratiakäsityksiä, tutkijoiden yhteiskunnallista roolia ja vastuuta sekä kriittisen akateemisen tiedontuotannon merkitystä.

Avainsanat: Kansalaisrohkeus, kansalaistottelemattomuus, kansalaisuus, yksilö, kollektiivi

\section{ABSTRACT}

\section{CIVIC COURAGE: DISOBEDIENT INDIVIDUALS, COMMUNITIES, RESEARCHERS}

-The article explores civic courage and civic disobedience from various perspectives, including individual and collective organising in struggles against injustice and inequality, tensions regarding the essence of citizenship, different conceptualisations of democracy, the societal role and responsibility of researchers, and the significance of critical academic knowledge production.

Key words: Civic courage, civic disobedience, citizenship, individual, collective 


\section{Johdanto}

$\mathrm{M}$ onet asiat, joita ainakin länsimaissa pidetään itsestäänselvyyksinä, kuten naisten äänioikeus, ovat rohkeutta vaatineiden kamppailujen tuloksia. Epäoikeudenmukaisuutta ja epätasa-arvoa vastaan on ryhdytty toimimaan. Tänäkin päivänä tasa-arvon ja oikeudenmukaisuuden puolustaminen vaatii itsensä likoon laittamista ja monesti myös avointa kansalaistottelemattomuutta. Mutta mitä kansalaisrohkeus on ja mitä se merkitsee nykyaikana? Millaista rohkeutta yhteiskunta yleensä sietää paremmin ja millaista huonommin? Millaista on tieteen ja tutkijoiden kansalaisrohkeus? Näitä teemoja pohdittiin Lapin yliopiston Tieteiden päivillä syyskuussa 2019 järjestetyssä Kansalaisrohkeus-paneelikeskustelussa, johon tekstin kirjoittajat osallistuivat ${ }^{1}$. Teksti on kirjoitettu keskustelun alustusten pohjalta.

Rohkeutta on filosofiassa ja myös teologiassa käsitelty paljon eettisenä ja poliittisena hyveenä. Kansalaisrohkeuden käsite herättelee pohtimaan asioita, joihin rohkeutta peilataan. Suhteutetaanko sitä kenties pelkoon tai arkuuteen vai pikemminkin passiivisuuteen ja tavallisuuteen? Onko kansalaisrohkeus jotakin poikkeuksellista vai voiko se olla myös arkipäiväistä ja tavanomaista? Onko se myös ajattelua ja vallitsevien normien sanallista kyseenalaistamista vai vaatiiko se aina tekoja, joiden myötä uhatuksi saattaa päätyä myös kehollinen koskemattomuus? Niin voi tapahtua erityisesti kansalaistottelemattomuudessa, jos toimija vaikkapa pyrkii estämään turvapaikanhakijan pakkopalauttamisen sotaa käyvään maahan tai kiinnittää itsensä puskutraktoriin metsähakkuiden esteeksi.

Maailma vaikuttaa elävän nyt järjestelmätason murroskohtaa, jonkinlaista politiikan tiivistymistä tai "hulluja vuosia”. "Tulevaisuus on jotenkin siirtynyt paikaltaan", kuten kirjailija Alexandr Grin kirjoitti Venäjän vallankumouksen edellä (ref. Aleksijevits 2018). Tällaisilla hetkillä, kun tulevaisuutta määritellään tavallista intensiivisemmin, kansalaisrohkeus on erityisen tärkeää. Murroskohdissa on edettävä kohti arvaamattomampaa tulevaisuutta, ja toisaalta arvaamattomuuden keskellä ihmisyyden perusarvojen merkitys korostuu. Myös tutkijoiden on tärkeää olla kamppailemassa siitä, millaiseksi ja kenen ehdoilla tulevaisuus muodostuu.

\footnotetext{
1 Paneelikeskustelun alkuperäinen idea on Eeva Luhtakallion, joka järjesti kansalaisrohkeuteen liittyvän paneelin Helsingin yliopiston Tieteiden päivillä tammikuussa 2019.
} 


\section{Kansalaisuudesta}

Puhe "kansalaisrohkeudesta" olettaa, että "kansalainen" on erityinen rooli ja identiteetti - miksi muuten puhuttaisiin kansalaisista ylipäätään? Ehkä kansalaisella on myös omanlaisensa rohkeuden muoto. Ennen kaikkea kansalaisen käsite on jännitteinen. Yhtäältä kansalainen tarkoittaa poliittista ihmistä erotuksena kuluttajasta, toisaalta ulossulkevan poliittisen yhteisön jäsentä erotuksena ihmisistä yleisesti.

Kansalaisen ja kaupallisen toimijan eronteko on tunnettu ainakin 1700-luvulta asti, jolloin Ranskassa citoyen ja bourgeios alkoivat saada eri merkityksiä: molemmat olivat tarkoittaneet kaupungin asukasta, käytännössä useimmiten kauppiasta, mutta vallankumouksen alla citoyen alkoi merkitä "itsensä hallitsijaa" eli poliittista ihmistä. Kansalaisuuteen ryhdyttiin liittämään osallistumisen ja kriittisyyden hyveitä, ja poliittinen osallistuminen alkoi erottua omaksi julkisen toiminnan tilakseen. (Brubaker 1989.)

Tänä päivänä kansalaisuuden vastapoolia kutsutaan useimmiten kuluttajan rooliksi. Kuluttajan rooli ei suuntaudu yhteiskunnan rakenteiden muuttamiseen vaan markkinatoimintaan. Kansalaisuus edellyttää avointa julkisuutta, kuluttajuus ei. Kansalaisuus on kriittistä ja refleksiivistä, kuluttaja tietää halunsa ja näkee muut ihmiset ja valtion välineeksi päämääriensä toteuttamiseen. Poliittiseen kansalaisuuteen sisältyy myös poliittisen tasa-arvon ihanne: kun käytetään etuliitettä "kansalais-", tarkoitetaan tyypillisesti sitä, että ihmiset ilman titteleitä tai muodollista valta-asemaa ovat päättäneet tarttua asiaan. Kun "kansalaiset" toimivat, kyseessä on kenen tahansa oikeus ja valta osallistua ja vaatia.

Kansalaiset ovat käytännössä myös hierarkkisessa asemassa suhteessa toisiinsa, joskin eri tavoin kuin kuluttajat. Toisilla on paremmat mahdollisuudet poliittiseen toimintaan kuin toisilla. Kansalainen tarkoittaa jonkin kaupungin (myöhemmin kansallisvaltion) muurien sisällä toimivaa ihmistä, tai yhteisön tunnustettua jäsentä. Tämä yhteisö on myös ulossulkeva, aivan kuten kaupunkilaisuus oli aikoinaan asema eikä pelkästään asuinpaikka. Kun kansalaisuus on valtaistumista valtiossa, se tarkoittaa samalla valtion normien, joidenkin annettujen identiteettien ja suhteiden omaksumista. Kärjistetysti: kun ihminen toimii "omilla kasvoillaan", se viittaa eetikkojen laajasti käsittelemään katseen voimaan ja tunnustukseen, mutta kun kansalainen toimii "omilla kasvoillaan", se viittaa tunnistettavuuteen pankkitunnuksilla tai sosiaaliturvatunnuksen avulla. Toisaalta kansalaisuus yhteiskunnan jäsenyytenä voi toteutua yhteiskunnal- 
lisessa osallistumisessa, vaikka muodollinen kansalaisuusasema puuttuisi (esim. Nivala \& Ryynänen 2019, 165-166). Tätä on kuvattu esimerkiksi käsitteellä kansalaisuuden teot (acts of citizenship, Isin 2008).

\section{Kansalaisuus, liikkeet ja tottelemattomuus}

Kansalainen on siis osallistuva hahmo, mutta kaikki osallistuminen ei ole rohkeutta. Osallistumista tapahtuu jatkuvasti erilaisten yhdistysten, toimikuntien ja kuulemisten kautta. Suurin osa tällaisesta toiminnasta ei ole mitenkään erityisen rohkeaa tai radikaalia vaan pikemmin osa yhteiskunnan normaalijärjestyksen uusintamista. Kansalaisen rohkeus taas tiivistyy hetkiin, jolloin tehdään jotakin odottamatonta, konventioita rikkovaa, tai uidaan valtavirtaa vastaan.

Usein käytetty esimerkki radikaalista ja rohkeasta kansalaistoiminnasta on kansalaistottelemattomuus. Kansalaistottelemattomuus on avointa ja julkista toimintaa jonkin asiantilan muuttamiseksi. Siinä rikotaan jotakin ongelmalliseksi koettua lakia tai säädöstä tarkoituksella ja julkisesti. Tästä lainrikkomisesta kannetaan mahdolliset seuraukset ja varotaan rikkomasta muita lakeja. Näin kansalaistottelemattomuus on (laittomuudestaan huolimatta) lopulta hyvin tarkkaa "oikeasta" toimintakoodista ja lisäksi omalla tavallaan varsin ennalta-arvattavaakin. Silti se edellyttää osallisiltaan valtavasti tahtoa ja rohkeutta taistella kannattamiensa asioiden puolesta.

Kenties tunnetuimpia esimerkkejä kansalaistottelemattomuudesta ovat luonnonsuojelukamppailut, joihin on liittynyt symbolista lain rikkomista. Ajankohtainen esimerkki on ilmastokriisin edellyttämää muutosta ajava Extinction Rebellion -liike, joka Suomessa toimii nimellä Elokapina. Perinteisempiä ovat itsenäisyyskamppailut, esimerkiksi Mohandas Karamchand eli Mahatma Gandhin (1869-1948) suolamarssi Intiassa vuonna 1930 , jolla vastustettiin brittihallinnon asettamaa suolaveroa. Tällaisten projektien tavoitteena on havainnollistaa vallitsevan lainsäädännön mielettömyyttä tuomalla laki ja siitä saatava rangaistus näkyviin. Esimerkiksi aseistakieltäytymiseen tai homoseksuaalisuuteen yllyttäminen on ollut Suomen historian joissakin vaiheissa kiellettyä, joten tällaisia lakeja protestoineet ovat esimerkiksi keränneet valtavan nimilistan ihmisiltä, jotka ovat tunnustaneet syyllistyneensä kyseiseen toimintaan yllyttämiseen. Hieman toisenlainen kansalaistottelemattomuuden muoto on avoin suora toiminta, joka ei kohdistu ainoastaan lain julkiseen kritiikkiin vaan ilmentää moraalista tunnetta lain rikkomisen välttämättömyydestä: esi- 
merkiksi pakolaisia merestä pelastavat alukset voivat nykylainsäädännön puitteissa syyllistyä rikokseen mutta jatkavat toimintaansa siitä huolimatta, koska pitävät ihmishenkien pelastamista moraalisesti ensisijaisena.

Kansalaistottelemattomuutta onkin perusteltu monin tavoin. Siinä missä liberalismin klassikko John Rawls (1921-2002) katsoi kansalaistottelemattomuuden olevan perusteltua nimenomaan julkisen huomion kiinnittämiseksi yhteiskunnan ongelmiin, toinen klassikko Gandhi vetosi moraaliseen totuuteen kansalaistottelemattomuuden oikeuttajana. Gandhin mukaan "totuudessa eläjä" tietää, mikä on oikein, ja toimiessaan täysin omilla kasvoillaan edustaa moraalista ylemmyyttä suhteessa pakkovaltaan.

Kansalaistottelemattomuuden ja sen sukulaiskäsitteiden merkitys ei palaudu siihen, että ne ovat joskus tehokkaita välineitä protestoida yksittäisiä lakeja vastaan. Laajemmin kyse on demokratiakäsityksestä. Karkeasti voidaan erottaa kaksi keskeistä tapaa ajatella, mitä demokratia on. Ensimmäisen mukaan demokratiassa on kysymys formaaleista proseduureista: demokratia toimii, kun vaalit ovat avoimet, edustusjärjestelmä toimii, politiikka on erotettu oikeudenkäytöstä ja niin edelleen. Tätä usein korostetaan "pulinat pois" -tyyppisillä sutkauksilla, joilla halutaan rajoittaa kansan vallankäyttö ainoastaan sen muodollisiin ilmentymiin, tyypillisesti vaaleihin. Vaikka voi tuntua siltä, että näin ajateltuna demokratia toimii, kyseessä on nimenomaan sen tuhon tie. Demokratia ei pysy pystyssä itsestään, vaan merkittävät taloudelliset ja poliittiset valtaintressit jatkuvasti heikentävät tasa-arvoista kansanvaltaa.

Siksi onkin käännettävä katse toiseen ja päällisin puolin paradoksaaliseen demokratiakäsitykseen: sen mukaan "toimiva demokratia on toimimatonta demokratiaa”. Formaalin prosessin lisäksi hyvässä yhteiskunnassa vallitsee aina jonkinlainen kitka. Kriittiset kansalaiset eivät silmänräpäyksessä suostu minkä tahansa päätöksen implementointiin vain siksi, että se on tehty demokraattisessa järjestyksessä. He haastavat, esittävät vaihtoehtoja, järjestäytyvät ja joskus asettuvat konkreettisesti poikkiteloin. Kriittisiä kansalaisia on vaikea johtaa - ja sen täytyykin olla vaikeaa. (Eskelinen 2019; Rosanvallon 2008.)

\section{Palvotut ja syrjityt yksilöt}

Kansalaisrohkeuden käsite herättelee kysymään, onko kyse ensisijaisesti ihmisten suhteesta valtioon, lakiin, sääntöihin ja vallitsevaan järjestelmään - vai voiko kansalaisrohkeus olla irrallaan näistä ja ilmentää jotakin 
syvällisempää asennetta maailmaa kohtaan. Lisäksi on kysyttävä, ovatko nämä rohkeat kansalaiset ainoastaan henkilökohtaisen moraalinsa johdattamia yksilöitä vai myös orgaanisen ja oppivan kansalaisliikkeen toimijoita. Ihmisten poliittinen asema yksilöinä eroaa merkittävästi ihmisten poliittisesta asemasta liikkeiden osina.

Kansalaisten rohkeudesta puhuttaessa huomion keskipisteenä ovat useimmiten poikkeukselliset yksilöt. Tottelemattomuudesta ja kansalaisrohkeudesta puhuttaessa kulttuurisen kuvaston täyttävät ikoniset kuvat periksiantamattomista yksilöistä, jotka uskovat ihanteisiinsa, vaikka järjestelmä olisi niitä vastaan. Tuntematon mies seisomassa tankin edessä Tiananmenin aukiolla Kiinassa. Apartheidin vastaisen kamppailun keulahahmo Nelson Mandela Etelä-Afrikassa. Yhdysvaltojen kansalaisoikeusliikkeen symboliksi noussut Rosa Parks, joka kieltäytyi antamasta bussissa tilaa valkoiselle, vaikka rotuerottelulakien mukaan näin olisi kuulunut tehdä.

Mutta onko rohkeus aina yksilön rohkeutta? Usein suurten muutosten hetket ovat nimenomaan yhdessä tekemisen ja toimimisen hetkiä. Tällaisten hetkien kuvastoon kuuluu esimerkiksi "Baltian käsiketju", jonka 30-vuotismerkkipäivää vietettiin elokuussa 2019. Tallinnasta Liettuaan yltänyt ketju, jossa ihmiset pitivät toisiaan kädestä, oli näyttävää ja urheaa. Se vaati jokaiselta osalliselta rohkeutta, mutta vasta toisiin luottaminen sai aikaan todellisen muutoksen, tehden sen myös näkyväksi. Jossain mitassa kaikki protestit vaativat tällaista spontaania ja keskinäiseen luottamukseen perustuvaa kollektiivia. Ryhmät ovat aina enemmän kuin osiensa summia. Kollektiivinen kansalaistoiminta on kuitenkin paljon mutkikkaampi taito kuin yksilön kansalaisrohkeus. On eri asia luottaa itseensä ja omaan ideologiaansa kuin luottaa toisiin. Toki kollektiivien rakentamiseen on hyväksi havaittuja käytäntöjä: esimerkiksi radikaaliliikkeet usein organisoituvat nopeasti päätöksiä tekeviin mutta turvallisuuden tunnetta lisääviin läheisryhmiin (affinity group).

Kertomukset rohkeista yksilöistä tulisi nähdä myös kontekstissa, jossa yksilön rohkeus on keskeinen osa kulttuurivetoisen kapitalismin itseymmärrystä. Kertomukset periksiantamattomista ja asiaansa uskovista yksilöistä sopivat nykykulttuuriin vaivaannuttavan hyvin. Äskettäin Barbie-nukkeja valmistava Mattel-yhtiö kertoi lanseeraavansa Rosa Parks -nuken. Mistä Rosa Parks -barbie kertoo? Varmasti esikuvien kirjosta, mutta myös siitä, että kansalaistottelemattomuus on vaarassa päätyä individualisoituneen kapitalismin polttoaineeksi. Nykyajan yksilöllisen me- 
nestyjämoraalin ytimessä ovat sellaiset kehotukset kuten uskalla tehdä, ole rohkea, usko itseesi, ota oma elämäsi haltuun ja tavoittele mahdotonta. On vaarana, että kertomukset kansalaisrohkeudesta päätyvät vahvistamaan järjestelmää, jota luonnehtii kaiken läpäisevä yrittäjähenkisyys ja yksilöllisyydellä hallinta. Ehkä rohkeat ja asiaansa uskovat yksilöt ovat kuitenkin helpommin hallittavissa kuin yhteiskunnallista muutosta tavoittelevat liikkeet. Esimerkiksi ranskalaisen politiikan teoreetikon Pierre Rosanvallonin (2008) mukaan osallistumisesta on tullut vallankäyttäjille korvaamaton ongelmien ja kansanosien tehokkaassa hallinnassa. Ainakin maailman muuttaminen on vaikeampaa, kun kollektiiviset utopiat paremmasta yhteiskunnasta haalistuvat yksilöllisiksi unelmiksi.

Yksilöllisyyden korostuminen ei ainakaan tarkoita, että aktivistien olisi helppoa saada poliittisia viestejään kuuluviin, päinvastoin. Kun liikkeet voimistuvat ja rikkovat hallittavia osallistumisen konventioita, niitä aletaan käsitellä uhkana. Monissa konteksteissa yhteiskunnallisiin liikkeisiin kuuluvien ihmisten ja aktivistien näkemyksiä, kokemuksia tai tietoa ei kuunnella ja huomioida riittävästi poliittisessa päätöksenteossa. Yhteiskunnalliset liikkeet ympäri maailmaa ovat yhä tiukemman valtiollisen hallinnan ja valvonnan kohteina. On hyvin tavallista, että hallitus ja viranomaiset uhkailevat aktivisteja, ja monissa maissa valtion harjoittama väkivalta aktivisteja kohtaan lisääntyy hälyttävästi. Usein aktivistit pyritään marginalisoimaan esimerkiksi esittämällä heidät "kehityksen jarruina".

Ei olekaan yllättävää, että yhteiskunnallisissa liikkeissä korostuu yhä vahvemmin autonomisuuden merkitys. Riippumattomuutta valtiosta ja sen instituutioista pidetään tärkeänä ja samalla korostetaan myös ei-hierarkkista paikallista organisoitumista, päätöksentekoa ja osallistumista. Riippumattomuus valtiosta tarkoittaa myös sitä, että aktivisteja on vaikeampi hallita yksilöinä ja kansalaisina.

\section{Tutkijan rohkeus}

Entä mitä ja minkälaista on tieteen ja tutkijoiden kansalaisrohkeus ja mitä siitä voi seurata? Miten yhdenvertaisuutta/tasa-arvoa, oikeudenmukaisuutta ja ekologista kestävyyttä voi sekä ilmentää että edistää yliopistoympäristössä, entä tutkimuksellisen yhteistoiminnan keinoin? Miten rooleja ja asetelmia käännetään? Mitä tarkoittaa tutkijan toiminnallinen rooli ja yhteiskunnallinen vastuu?

Nyky-yliopisto saattaa vaikuttaa liukuneen varsin kauas kansalaisrohkeudesta. Yliopistojen ja koulutusohjelmien tavoitteissa ei enää juurikaan 
viitata aivan keskeiseen yliopiston kasvatukselliseen tehtävään eli kriittisen ajattelu- ja reflektiokyvyn harjaannuttamiseen. Sen sijaan puhutaan esimerkiksi yhteistyöstä elinkeinoelämän ja työmarkkinoiden kanssa sekä korostetaan opintojen työelämälähtöisyyttä ja tavoiteajassa valmistumista. Vaarana on, kuten filosofi Martha Nussbaum (2010) on huomauttanut, että yliopisto alkaa tuottaa lähinnä teknistä asiantuntijuutta - työ- ja elinkeinoelämää täydellisinä, joustavina, kaikkeen venyvinä työntekijöinä, kaupallistettavien innovaatioiden tuottajina palvelevia ihmisiä. Tällöin sivuun jäävät ajattelun, refleksiivisyyden ja yhteistoiminnan hyveet sekä kyky lukea yhteiskuntaa kriittisesti, nähdä yhteiskunnallisia muutoksen tarpeita ja toimia yhdessä niiden toteutumiseksi. (Nussbaum 2010.)

Portugalilainen sosiologi Boaventura de Sousa Santos (2004) on puolestaan todennut, että "tilanteessa, jossa globaali kapitalismi pyrkii tekemään yliopistosta jatkeensa ja itse asiassa muuttamaan sen laajaksi omia tavoitteitaan palvelevaksi toimijaksi, yliopiston tulee nostaa yhteiskunnallinen toimijuus keskeisempään rooliin, ymmärtäen se vaihtoehdoksi globaalille kapitalismille. Yliopistojen tulee osallistua aktiivisesti sosiaalisen yhteenkuuluvuuden edistämiseen, demokratian syventämiseen, taisteluun syrjäytymistä ja ympäristön tilan heikkenemistä vastaan, kulttuurisen moninaisuuden puolustamiseen.” Oppia Santosin peräänkuuluttamaan yhteiskunnalliseen toimijuuteen voi hakea esimerkiksi yhteiskuntatieteiden historiasta, josta tunnetaan nykyisin esimerkiksi aktivistitutkimukseksi tai taistelevaksi tutkimukseksi kutsuttu tutkimusote (esim. Brown \& Strega 2005; Croteau, Hoynes \& Ryan 2005; Hale 2008; Sudbury \& Okazawa-Rey 2009; Suoranta \& Ryynänen 2014).

Ennen 1900-lukua suuri osa yhteiskuntatieteilijöistä työskenteli osin tai kokonaan yliopiston ulkopuolella. Monet niistä teoreetikoista, joita nyt nimitämme yhteiskuntatieteiden klassikoiksi, kuten taloustieteilijä Thorstein Veblen (1857-1929) tai yhteisösosiaalityön pioneeri Jane Addams (1860-1935), olivat nykytermein nimenomaan aktivistitutkijoita tai taistelevia tutkijoita. He halusivat työllään paitsi tuottaa uutta tietoa myös edistää yhteiskunnan inhimillistymistä. He tosin päätyivät monenlaisiin kahnauksiin yliopistoinstituution kanssa. Veblen erotettiin yliopistosta ammattiliittoja puolustavien näkemystensä vuoksi ja Addams kollegoineen eristettiin tieteellistä identiteettiään 1900-luvun alussa rakentaneesta sosiologiasta, koska heidän toimintansa ihmisten parissa koettiin epätieteelliseksi ja epäteoreettiseksi.

Myös nykytutkijoiden osallistuminen tutkimuksen kautta ja tutkijoi- 
na esimerkiksi yhteiskunnallisen tasa-arvon ja oikeudenmukaisuuden tai kestävän elämän edistämiseen saatetaan usein ohittaa ja mitätöidä vaatimalla tieteeltä ja tutkimukselta sellaista neutraaliutta ja objektiivisuutta, johon kannanotot tai tutkijoiden aktivismi eivät istu. Pilkahduksia rohkeudesta löytyy kuitenkin myös nyky-yliopistosta. Niitä ovat esimerkiksi erilaiset yliopiston sisäiset kamppailut, kuten vuonna 2009 voimaan tulleen yliopistolakiuudistuksen vastustaminen tai Koulutuslakko-liikkeen vuoden 2015 yliopistovaltaukset.

\section{Rohkeus ja marginaalit}

Aktivistitutkijuuden yhteydessä on tärkeää muistaa, että ihmiset ovat hyvin eriarvoisissa yhteiskunnallisissa asemissa. "Rohkeus" psykologisena käsitteenä saattaa johtaa ajattelemaan, että kyse on vain yksilön asennoitumisesta. Kuitenkaan kaikille kansalaisrohkeus ei ole valinnan kysymys, sillä usein niillä ryhmillä, jotka ovat yhteiskunnassa alisteisessa asemassa, ei ole muuta vaihtoehtoa kuin olla rohkea. Esimerkiksi sukupuoli- ja seksuaalivähemmistöt, maahanmuuttajat, pakolaiset ja etniset vähemmistöt eri puolilla maailmaa joutuvat käymään jatkuvaa, uuvuttavaa kamppailua perus- ja ihmisoikeuksistaan. Myös yhteiskunnallisesti etuoikeutetussa asemassa olevien ihmisten, jotka eivät samalla tavoin itse kohtaa syrjäyttämisen tai väkivallan uhkaa, tulisi kantaa vastuuta rohkeista teoista yhteiskunnallisesti marginalisoitujen ryhmien rinnalla toimien. Näiltä ryhmiltä itseltään tulee kuitenkin aina kysyä, mitä heidän mukanaan ja heidän tuekseen voi ja kannattaa tehdä. Tämä on erittäin tärkeä elementti liittolaisuudessa (ks. esim. Land 2015; Nagar 2014; Tuck \& Yang 2012; Tuhiwai-Smith 1999).

Eräs keino tukea marginaalien äänten voimistumista tutkimuksen keinoin on niin kutsuttu esilläpitotutkimus. Siinä nostetaan näkyviin ilmiöitä, jotka muuten jäisivät piiloon, ja pyritään edistämään niistä käytävää julkista keskustelua. Kyse ei kuitenkaan ole äänen "antamisesta" marginalisoiduille tai sorretuille ihmisryhmille, kuten usein kuulee ilmaistavan, vaan piiloon jäävien äänten voimistamisesta sen vallan ja niiden etuoikeuksien avulla, joita tutkijoilla on käytössä asemansa myötä. Tätä valtaa voidaan käyttää monella tavoin. Esilläpitotutkimus voi olla myös huolellista paneutumista sellaisiin yhteiskunnan katvealueisiin, joista ei vielä tiedetä riittävästi tai joista ei julkisuudessa puhuta, koska valtaa pitävien näkökulmasta kaikki tieto ei ole tervetullutta. (Suoranta \& Ryynänen 2014.)

Samaan aikaan on syytä ottaa yhä vakavammin huomioon se kritiik- 
ki, jota yhteiskunnalliset liikkeet kohdistavat akateemiseen tiedontuotantoon. Monissa liikkeissä suhtaudutaan sangen epäilevästi akateemiseen tutkimukseen, koska sen nähdään olevan liian teoreettista tai abstraktia ja tuottavan liikkeiden sijasta hyötyä pikemminkin tutkijalle itselleen. Usein aktivistit korostavat, että tutkijoiden ei pitäisi vain tutkia, vaan heidän tulisi olla samalla myös aktivisteja ja tukea konkreettisesti tutkimiensa liikkeiden toimintaa. Aktivistit eivät yleensä itse pidä omaa aktivismiaan ammattina tai työnä, vaan korostavat sen olevan ensisijaisesti elämäntapa yhtä aikaa henkilökohtainen ja poliittinen valinta sekä yhteiskunnallinen velvollisuus, josta ei ole odotettavissa henkilökohtaista hyötyä, kunniaa tai mainetta vaan pikemminkin suuria ongelmia ja vaikeuksia. (Seppälä 2016.) Esilläpitotutkimusta selkeämmin kansalaisrohkeuden alueelle tuleekin sellainen aktivistinen tutkimus, joka pyrkii suoraviivaisemmin ja yhteistoiminnallisesti, osallistuen ja osallistumaan innostaen muuttamaan vallitsevia asiantiloja (ks. Suoranta \& Ryynänen 2014).

Vastatiedon tuotannolla on kaiken kaikkiaan nykyaikana tärkeä rooli. Nykyinen hallintajärjestelmä perustuu vahvasti asiantuntijuuteen, ja merkittävä osa politiikasta esiintyy neutraalina hallinnointina. Tämä tekee kansalaisten vastarinnasta vaikeampaa: on pystyttävä osoittamaan vallitsevan tiedon näkökulmasidonnaisuus tuottamalla omaa tietoa ja haastettava vallitsevia oletuksia siitä, mikä on järkevää tai tarkoituksenmukaista. Tässä prosessissa tutkimus voi tukea yhteiskunnallisia liikkeitä tärkeällä tavalla.

Tutkijoiden valta tarkoittaa kuitenkin paitsi mahdollisuuksia käyttää tuota valtaa hyvin, myös velvollisuutta olla tietoinen valtansa seurauksista. Tutkijoiden asema suhteessa tutkittaviin aktivisteihin tai muihin kansalaistottelemattomuuden subjekteihin on usein korostetun etuoikeutettu. Heidän ei esimerkiksi tarvitse aktivistien tavoin pelätä koko ajan turvallisuutensa puolesta. Pikemmin he hyötyvät tutkimuksesta meritoitumisen kautta. Siksi on tärkeää, että tutkijat koko ajan pohtivat millaisia tietovalta-suhteita tutkimuksessa rakentuu, reflektoivat kriittisesti omia etuoikeuksiaan ja myös "poisoppivat" tietyistä perinteisistä, hierarkkisia valtasuhteita uusintavista tieteellisistä käytännöistä ja tiedontuotannon tavoista - toisin sanoen hylkäävät osan siitä, mitä heille on opetettu. Tällaista lähestymistapaa on korostettu erityisesti jälkikoloniaalisen tutkimuksen piirissä, jossa siihen on viitattu "episteemisenä tottelemattomuutena" (Mignolo 2010). 


\section{Lopuksi}

Kansalaisuus on aina jännitteinen rooli. Ei ole sattumaa, että englannin sana subject viittaa yhtä aikaa toimijaan ja alamaiseen: the political subject a subject of her majesty the queen. Kansalaisuuteen sisältyy mahdollisuus vaatia valtaa marginaaleille ja laajentaa poliittista tilaa ja toisaalta vaara typistää toiminta hallittuun, harmittomaan ja ulossulkevaan osallistumiseen. Slavoj Žižekin erään monista lentävistä lauseista mukaan radikaali kansalaistoiminta on oman negaationsa sisältävä käsite samaan tapaan kuin kofeiiniton kahvi (esim. Peltokoski 2004). Jotkut tutkijat ovat kuitenkin huomauttaneet, että radikaali toiminta laajentaa kansalaisuutta.

Uusliberalismin aikakaudella kansalaisrohkeutta tarvitaan monilla eri tasoilla ja monenlaisten toimijoiden taholta - niin kansalaisten, tutkijoiden kuin aktivistienkin toimesta. Joskus yksittäisen ihmisen, kuten erään ruotsalaisen koulutytön, kansalaisrohkeus voi toimia liikkeelle laittavana sysäyksenä muutokselle, mutta rakenteellisen epäoikeudenmukaisuuden ja epätasa-arvon kyllästämä maailma voi muuttua radikaalisti vain, jos tarpeeksi monet uskaltavat toimia, olla rohkeita ja tottelemattomia yhdessä.

\section{LÄHTEET}

Aleksijevits, S. 2018. Neuvostoihmisen loppu. Helsinki: Tammi.

Brown, L. \& Strega, S. (eds.) 2005. Research as Resistance. Critical, Indigenous \& Anti-oppressive Practices. Toronto: Canadian Scholars' Press/Women's Press.

Brubaker, W. R. 1989. The French Revolution and the Invention of Citizenship. French Politics and Society 7(3), 30-49.

Croteau, D., Hoynes, W. \& Ryan, C. (eds.) 2005. Rhyming Hope and History. Activists, Academics, and Social Movement Scholarship. Minneapolis \& London: University of Minneapolis Press.

Eskelinen, T. 2019. Demokratia utopiana ja sen vastavoimat. Tampere: Vastapaino.

Hale, C. R. (ed.) 2008. Engaging Contradictions. Theory, Politics, and Methods of Activist Scholarship. Berkeley \& Los Angeles: University of California Press.

Isin, E. F. 2008. Theorizing acts of citizenship. Teoksessa E. F. Isin \& G. M. Nielsen (eds.) Acts of Citizenship. London: Zed Books, 15-43.

Land, C. 2015. Decolonizing Solidarity. Dilemmas and Directions for Supporters of Indigenous Struggles. Lontoo: Zed Books. 
Mignolo, W. 2010. Epistemic Disobedience, Independent Thought and Decolonial Freedom. Theory, Culture \& Society 26 (7-8), 159-181. Saatavissa https://doi. org/10.1177/0263276409349275.

Nagar, R. 2014. Muddying the Waters. Coauthoring Feminisms Across Scholarship and Activism. Chicago: University of Illinois Press.

Nivala, E. \& Ryynänen, S. 2019. Sosiaalipedagogiikka - kohti inhimillisempää yhteiskuntaa. Helsinki: Gaudeamus.

Nussbaum, M. 2010. Not for profit. Why democracy needs the humanities. Princeton \& Oxford: Princeton University Press.

Peltokoski, J. 2004. Radikaalia kansalaistoimintaa ja kofeiinitonta kahvia. Megafoni 08.07.2004.

Rosanvallon, P. 2008. Vastademokratia. Politiikka epäluulon aikakaudella. Suomennos Tapani Kilpeläinen. Tampere: Vastapaino.

Santos, B. de S. 2004. Tesis para una universidad pautada por la ciencia postmoderna. Educación Superior: Cifras y Hechos, 18.

Seppälä, T. 2016. Feminizing Resistance, Decolonizing Solidarity. Contesting Neoliberal Development in the Global South. Journal of Resistance Studies 2 (1), 12-47.

Sudbury, J. \& Okazawa-Rey, M. (eds.) 2009. Activist Scholarship. Antiracism, Feminism, and Social Change. Boulder \& London: Paradigm Publishers.

Suoranta, J. \& Ryynänen, S. 2014. Taisteleva tutkimus. Helsinki: Into Kustannus.

Tuck, E. \& Yang, W. K. 2012. Decolonization is not a Metaphor. Decolonization: Indigeneity, Education and Society 1 (1), 1-40.

Tuhiwai-Smith, L. 1999. Decolonizing Methodologies. Research and Indigenous Peoples. Lontoo: Zed Books. 